\title{
CASA ESSAY
}

The paper judged to be the best student essay submitted to Akroterion by December 8, preceding publication of the volume for that specific year, is published annually as the CASA / KVSA Essay. The competition, which is sponsored by the Classical Association of South Africa, is open to undergraduate students every year and to Honours students in even-numbered years. The winner receives a cash prize of R800.

\section{CATULLUS 22 \\ HOI NEOTEROI: EVERYMAN'S VERSE OR SUPERCILLIOUS SNOBBERY?}

Natasje van der Westhuizen, Latin II (Stellenbosch University)

\section{Catullus 22}

(with own translation)

Suffenus iste, Vare, quem probe nosti, homo est venustus et dicax et urbanus, idemque longe plurimos facit versus. puto esse ego illi milia aut decem aut plura perscripta, nec sicut fit in palimpsesto relata; chartae regiae novi libri, novi umbilici, lora rubra, membranae, derecta plumbo et pumice omnia aequata. haec cum legas tu, bellus ille et urbanus Suffenus unus caprimulgus aut fossor rursus videtur; tantum abhorret ac mutat. hoc quid putemus esse? qui modo scurra aut siquid hac re tritius videbatur, idem infaceto est infacetior rure simal poemata attigit, neque idem umquam aeque est beatus ac poema cum scribit; tam gaudet in se tamque se ipse miratur. nimirum idem omnes fallimur, neque est quisquam, quem non in aliqua re videre Suffenum possis. suus cuique attributus est error, sed non videmus manticae quod in tergo est. 
That Suffenus whom you know so well, Varus, Is man of wit and word and worldly charm, The very same who many lengthy verses writes. Ten thousand or more, I put them at, all finished And written not as wont on palimpsest; (But on) clean pages fit for kings, And newly rolled, with red thongs and parchment bound, all lead-lined and pumice-smoothed. But when you read them, that pleasant And urbane old man Suffenus a goatherd and buffoon appears; so fickle and changed is he. How can this be put? He who once a dandy fellow Or something even better seemed, Is yet more lumb'ring than lumb'ring villains ${ }^{1}$ come When hacking at a poem - and still is never more content than when a-hacking sits;

So happy with himself is he, and thinks himself so Grand. In truth we're all thus flawed, and none there Is whom you can not in some thing see to be Suffenous. ${ }^{2}$ To each is gifted his own flaw, But we see not those bags on our own backs.

Gaius Valerius Catullus, doctus poeta according to Martial, is generally believed to have lived between the years $84-54 \mathrm{BC} .^{3} \mathrm{He}$ is more specifically regarded as a leading figure of the poetae novi, literally "new poets" or purveyors of Neoteric poetics (from the term hoi neoteroi, given to them by Cicero) (Johnson 2007:175). This group of poets, considered thus in retrospect by scholars intent on categorization, numbered amongst them (besides Catullus) M. Furius Bibaculus, C. Licinius Calvus, C. Helvius Cinna, Q. Cornificius, L. Ticida and P. Terentius Varro Atacinus, figures identified by Johnson as "the usual Neoteric suspects" (2007:176).

Inspired by translation of Sir Richard Francis Burton, 1894.

Lee translation 1990.

3 In the introduction to Skinner 2003, this belief is challenged and convincing evidence provided to suggest that Catullus did not in fact die of a broken heart at the tragically young age of 30 (a conclusion suited to the Romantic sensibility of Schwabe when he asserted thus in 1862 and one that continues to influence current views of Catullus), but that he may have returned to Verona in 54 to live out a long life as prominent public figure (I would like to thank Dr Suzanne Sharland for bringing this to my attention). 
The verses produced by these poets were remarkable in that they were a progressive step in response to and away from traditional Roman poetics and the ideals that surrounded them. These poets were disillusioned with the Roman ideal of duty and distrustful of the heroic to such an extent that their work became highly parodic (Johnson 2007:187). In this they followed the example of the Alexandrian Greek poet Callimachus, who championed poetry that was "concentrated, subtle, erudite and allusive, the result of much thought and revision" (Lee 1990:xxiii), as opposed to the lengthy traditional poetry still practised and developed by Cicero at the time. The verbose, the orotund and the large-scale were attacked by the Neoterics and the brief, the witty and the precise were praised. These poets' taste for the small was not only manifest in their choice of subject matter (ordinary everyday events and emotions were preferred to heroic tales), but also in "manner" - "the Neoterics were zealous in their search for artistic precision, for the restraint and constant revision ... that an obsession with craftsmanship imposed on the production of their poems" (Johnson 2007:188). This demand for elegance extended from their writing style to the physical manifestation of poetry. That is, the small libellus was preferred to the liber. In fact, Callimachus is well known to have said that "a big book is big trouble" (Lee 1990:xiii). My question, however, is this: What was their agenda? What kind of real responsibility were they taking upon themselves, or were they simply a clan of idle youths, flinging words at one another in play, and sniggering behind the backs of older, drier men? This essay investigates Catullus' poem 22 as a vessel for the possible answers to these questions.

The almost juvenile preoccupation with the size of books of poetry is one of the motivating factors for my choice of poem, revealing as it is of the mindset and social habits of the circle around Catullus. In poem 22, Catullus mounts an unflinching attack on one Suffenus, who has published a great many verses in several libri. He complains repeatedly of the length of and astonishing quality of the paper (or waste of good paper) upon which Suffenus' milia ... decem [versos] ("ten thousand verses", 22.4) are written. It is not long before the quality of Suffenus' poetry and even his personality fall prey to Catullus' lepidus. From this it would seem to follow that, for Catullus, the book opens up a door to the man, a point to which this essay returns.

At this stage it becomes important to refer to the style of discourse Catullus makes use of, and, as Krostenko terms them, "some Catullan keywords" (2007:212). Particularly in the Polymetra (of which poem 22 is one), a set of words has been established as reflecting Catullus' poetic, social and erotic standards (Krostenko 2007:212). The most commonly found are lepidus ("charming"), venustus ("attractive"), bellus ("neat"), and facetus ("witty") in broad definition (ibid). These words recur in Catullus, serving to express not only his own values, 
tastes and sensibilities, but those of the social elite to which he belonged. His family

was of high standing and wealthy (Caesar would stay with them at their home in Cisalpine Gaul when making his gubernatorial circuit), (Balme 1997:102) which enabled Catullus ultimately to serve as his own editor and publish his own books (Lee 1990:xiii). It may further have made it possible for him to live the kind of leisurely life reflected in his poems. When Catullus came to Rome from his native Verona, he soon became part of a circle within which these very words were in frequent use "apprais[ing] the attractiveness of literary composition and social presentation", a usage that, as expounded upon by Krostenko (2007:212-213), often had ambiguous connotations. This brings me to the second reason behind my choice of poem 22, that is, my interest in the relationships between Catullus and the individuals he addresses in or, to whom he dedicates, selected poems.

Krostenko posits that Catullus' use of these words allows him to "[comment] pointedly on the habits of appraisal of elite culture and thus of political life, in which appraisal figured and in which struggles over evaluative language were regular" (Krostenko 2007:212). He further writes that "those habits are revealed in stark clarity by a poet who, if he was in foro otiosis (sic) [relaxed in the forum], was perfectly alert in his leisure" (ibid). Catullus' alertness where social and poetic matters were at stake provokes an interesting answer to the questions of his agenda and sense of responsibility. What is most interesting about the "small, elegant and highly self-conscious social circle" to which Catullus belonged is that the greater bulk of Catullus' libellus seems to reflect, if not proclaim, the "passions and peccadilloes" of its members (Krostenko 2007:213). There is furthermore a distinct playfulness about the fact that a very large number of Catullus' poems seem, despite having been printed for consumption by the public, to have been directed at the attention of a few specific individuals. Besides poem 22, which is directed at one Varus, poem 1, which dedicates the volume, speaks directly and exclusively to Cornelius (1.1), the historian Cornelius Nepos (Balme 1997:103). Another example is poem 50, which takes the tone of a private (and intimate) letter to Licinius Calvus, reflecting upon the day Catullus had spent with him, writing versiculos ... numero modo hoc modo illoc ("short verses, now in this metre, now in that", 50:4-5), and the sleepless night Catullus had experienced afterwards.

That some of his poems seem to be intended to place the reader in a rather awkward, voyeuristic point of view is evident in an example like poem 14 . Catullus is chastising Calvus for sending him a horribilem et sacrem libellum ("horrible and cursed little book") full of the work of bad poets, and promises him that: 
non non hic tibi, salse, sic abibit.

nam, si luxerit, ad librariorum

curram scrinia, Caesios, Aquinos,

Suffenum, omnia colligam venena,

ac his suppliciis remunerabor.

No, not like this will it end for you, my witty

friend. For, when it is light, to the booksellers'

shelves I'll haste, and Caesius, Aquinus,

Suffenus, all the poisons will I collect and with

these punishments repay you.

Here the reader seems to peek into a private game, or a series of pranks between friends. The tone is ever charming and witty, and yet the closeness of the friendship between Calvus and Catullus, not to mention the acceptance of the truth of the lack of value of the poets / poisons mentioned in the poem and the open mocking of them, shed a stark light on the bonds that connected the members of Catullus' circle. The irreverence with which the poets Caesius, Aquinus and Suffenus are discussed reflects firstly the Neoteric attitude towards traditional poetry and its writers and secondly informs us of the kind of attitude they thought was acceptable and made a point of having towards those they disagreed with or did not like. These are but a few examples of poems that are so immodest in the public view that one is tempted to consider whether the publication of Catullus' novum libellum was not perhaps solely for the attention of his own circle, and that its being read by any one outside of that circle would be purely incidental. Poem 14 leads us back to the unfortunate figure of Suffenus, the target of Catullus' unflinching wit in the latter poem and the one this paper discusses.

Poem 22 is one of a subsection of the Polymetrics that Lee calls "the homosexual group of Juventius poems" (i.e. 15-26) (1990;xiv). The hints at homosexual relationships are not as manifest in poem 22 as they are in the surrounding poems, but its inclusion amongst these establishes it even more firmly in my interpretation as a window into the private lives of Catullus' circle. The poem is addressed to Varus (of the Polymetric poems, poem 10 is also addressed to him), and seems to test Varus' knowledge of the true nature of the seemingly venustus ... dica et urbanus ("charming ... witty and urbane") Suffenus with the clause quem probe nosti ("whom you know so well", 22.1-2). In fact, Suffenus' outward appearance is revealed as masking a less worthy inside, just like his novi libri (22.6), which, once you look inside, disappoint: versus /... cum legas 
tu, bellus ille et urbanus / Suffenus unus caprimulgus aut fossor / rursus videtur ("but when you read them, / that pleasant / and urbane old man Suffenus, a goatherd / and buffoon appears", 22.3; 9-11). This image sheds an interesting light on poem 1, wherein Catullus gives a novum libellum, also fresh from the pumice-stone (arida modo pumice expolitum), to Cornelius Nepos (1.1). If the metaphor were to be read deeper into this parallel, it would be seen that, unlike Suffenus' big new book, Catullus' little volume is as lepidum inside as it is outside, and by implication, as Putnam points out (1968:554), Catullus himself, since he is lepidus like his libellus, is worth inside as much as he is on the outside. This would seem to point towards the value attached by Catullus to integrity. The same does not apply to the fossor rursus Suffenus (22.10-11), whose regiae (royal) pages are marked with awkward verse. The distinction between urban / urbane as good and rural / rustic as bad (or at least rursus "backward" and infaceto "awkard" (22.14) is characteristic of the Neoteric paradigm.

Another of Catullus' Neoteric tendencies comes to the fore in the mention that Suffenus does not write his verse in palimpsesto (22.5). His formulation, nec sicut fit in palimpsesto ("and written not as wont on palimpsest"), implies that Suffenus' consumption of page upon page of new, kingly paper for his verse goes against the very grain of what Catullus believed poetic practice ought to be. Less overtly, Catullus seems to imply that the use of new paper makes impossible the careful reworking and rewriting of verse that the Neoterics admired and strove towards, as if palimpsestus, having been used and reused, bore the marks of previous toil and so contributed symbolically to the Neoteric ideal. Furthermore, the very fact that Suffenus' verses needed libri to hold them all (several volumes) would have evoked the ire of the new poets, whose short poems needed only libelli.

The poem portrays an every-day situation, true to the form of Neoteric verse-content, of one man who has met another only to have had the good impression the latter made upon the former eviscerated upon his reading the man's poems and discovering him to be less than he seemed to be in person. In this poem Catullus explores the experience of being fooled by appearances and presumption alike and, in the "Horatian" last four lines (Lee 1990:1540), comments on the vanity of any man who thinks he is without fault. This phrase is especially resonant at this point in the poem, when Catullus has just mocked a man for thinking himself without flaw, as it implies that Catullus may be guilty of the same oversight: sed non videmus manticae quod in tergo est (but we see not those bags on our own backs, 22.21). On a very superficial level, the first person plural verb 
tells us (not without effect) that Catullus includes himself in the number of people unaware of the flaws they carry in sacks on their backs. ${ }^{4}$

By repeating "tam" in line 17 (tam gaudet in se tamque se ipse miratur "so happy with himself is he, and thinks himself so grand") Catullus emphasizes his distaste at Suffenus' vanity at his own success. There seems to be no doubt in his mind that Suffenus is a bad poet - he goes as far as to imply that the fault Suffenus cannot spot on his own back, is his poetry itself. It cannot be denied, nevertheless, that the mocking tone of the poem is all but muted by the closing four lines. The punch-line of the poem, if you like, lies in the idea that Suffenus cannot see his own fault. The risibility is immediately muted, however, by Catullus' use of the first person verb: (non) videmus. He cannot escape from his own declaration of how the world is. This near self-chastisement or warning to the self is most clear when he writes that neque est quisquam / quem non in aliqua re videre Suffenum / possis ("and none there / is whom you can not in some thing see to be / Suffenous", 22.19-20). As Krostenko argues, Catullus must "appeal to an entirely different value system", wherein he must necessarily leave his position of young boy and step into that of the old man he is ridiculing. "In that", Krostenko continues, "there is testimony to the totality of the ethos our keywords encode" (2007:224), and furthermore to the broader agenda of the Neoterics.

This warning, although fleeting and easily taken lightly, must necessarily have been heard by the poets in Catullus' circle, intent as they were on artistic precision and sincere exploration of new emotions, and interpreted as reminder not to become too inflated, or tumidus "swollen" (like Antimachus in poem 95). Furthermore, the prioritization of the personal necessitates self-reflection, the very thing embodied in that line - "Lest we forget", he seems to be saying, "that to some other poet, we are Suffenus".

In conclusion, although this poem provides but one example of the many facets of the Neoteric movement as embodied in Catullus, it nevertheless illustrates rather vividly the social mores of a circle prone to a public kind of personal life, and moreover of the mindset of one of a group of men who, whilst making sweeping changes in the poetic world, nevertheless was anxious about his own legacy, acutely aware of his limits as a human being and fearing himself a "possible Suffenus". And here lies the most important point. It is only while

4 As Dr Suzanne Sharland has brought to my attention, the idea of the hidden sack on a man's back may be traced to, amongst other sources, Aesop's fable (here translated from Phaedrus's Latin text (4.10) by Christopher Smart 1913): "Great Jove, in his paternal care / Has given man two bags to bear; / That which his own default contains; / Behind his back unseen remains; / But that which others' vices attests / Swags full in view before our breasts. / Hence we're inevitably blind, / Relating to the Bag behind; / But when our neighbours misdemean, / Our censures are exceeding keen”. 
Catullus falls under his own scrutiny as poetic revolutionary that a true breach can be made from the heroism of the Roman tradition he distrusted. For as long as Catullus was keeping himself and his fellow man down to earth, fewer heroes could rise.

\section{BIBLIOGRAPHY}

Balme, M \& Morwood, J 1997. Oxford Latin Reader. Oxford: Oxford University Press.

Burton, Sir R F 1984. Accessed online 26/08/2010 at:

http://www.perseus.tufts.edu/hopper/text?doc=Perseus\%3Atext\%3A1999.

$02.0005 \% 3$ Apoem $\% 3 \mathrm{D} 22$

Johnson, W R 2007. Neoteric poetics. In Skinner, M B (ed.) A companion to Catullus, 212-232. Malden: Blackwell Publishing.

Krostenko, B A 2007. Catullus and elite Republican social discourse. In Skinner, M B (ed.), A companion to Catullus, 212-232. Malden: Blackwell Publishing.

Lee, G (ed., trans.) 1990. The poems of Catullus. Oxford: Clarendon Press.

Putman, M C J 1968. Catullus 22.13. Hermes 96.4:552-558.

Skinner, M 2003. Catullus in Verona. A reading of the elegiac libellus, poems 65-116. Columbus: The Ohio State University Press.

Smart, C (trans.) 1913. Phaedrus. The fables of Phaedrus translated into English verse. London: G Bell \& Sons, Ltd. 